\title{
Examination of Expection and Anxiety States in the Science
}

\section{Laboratory in Science Education}

\author{
Elvan İNCE AKA ${ }^{1 *}$ \\ ${ }^{1}$ Gazi University, Ankara, Turkey \\ ${ }^{*}$ Elvan İNCE AKA, E-mail: e.ince.aka@gmail.com
}

Received: August 28, 2017 Accepted: September 20, 2017 Online Published: September 22, 2017 doi:10.22158/wjer.v4n4p537 URL: http://dx.doi.org/10.22158/wjer.v4n4p537

\begin{abstract}
In this research, it is aimed to study the expectations and anxiety states of students, studying Science Education, during the course of science education laboratory practices. Screening model was used in this research. The research was carried out with the participation of 83 students, who took the course of Science Education Laboratory Practice and who were studying in 3rd Grade (3 branches) in the Department of Science Education, Department of Mathematics and Sciences, Faculty of Education, public university in the spring semester of 2016-2017 academic year. We used the following open-ended research question; "What are your expectations from the course of Science education laboratory practices as a data collection tool?", and we also used "Science Laboratory Anxiety Scale” which was developed by Uşaklı and Akpınar (2015). Descriptive analysis technique was used during the analysis of qualitative data. SPSS 18.0 package statistics program was used during the analysis of quantitative data. In line with the research results, it is observed that the expectations and anxieties of students related with science laboratory are focused mostly on the level of success.
\end{abstract}

\section{Keywords}

science education, science laboratory, anxieties, expectations

\section{Introduction}

Physical sciences come to the forefront by allowing the students to ask questions, to develop the skill to make researches, to hypothesise and to interpret the obtained results while laying emphasis on tests, observations and explorations (Balagun \& Odubunni, 1991). This character of physical sciences draws attention to the science laboratory, which is the most important active learning environment of all in Science education since it is suggested that it is appropriate to display any scientific subjects, which the students have difficulty in understanding, in laboratory environments where learning is achieved by actually performing and experiencing such scientific subjects (Çallıca, Erol, Sezgin, \& Kavcar, 2001). Science laboratories are the learning environments where the students establish scientific information, 
where they improve their basic scientific thinking skills and where they interact with each other during this process (Hofstein \& Lunetta, 2004). Shulman and Tamir (1973) argue that the students make progress in several areas with the utilization of laboratories during science education, and several of these areas listed among affective skills, such as understanding the nature of sciences, curiosity, interest, requirement and trust, etc. Bloom emphasizes that there are evidences, which prove that there is a significant relationship between affective characteristics and success level, and that affective characteristics play a critical role in determination and influence of success (Bloom, 1979). It must be considered that, during this process, there are cognitive characteristics that have effect on learning, as well as various other factors, such as positive and negative attitudes, requirements, expectations, interest areas of students and motivation, etc. Affective dimensions of learning, such as anxiety, attitudes and self-efficacy, are perceived as important predictors of students' performance in laboratory environment (Bowen, 1999). Anxiety plays a critical role among such negative emotions (Laukenmaan et al., 2003). Freud (1969) defines anxiety as "something that may be experienced at any time and anywhere, a mood that is undesired and unpleasant". Mallow (1986) defines science anxiety as disgust or fear from science concepts, scientists and activities related with science. In the literature, although there are many researches about science and chemistry anxiety (Eddy, 2000; Huey, 2013; Kurbanoglu \& Akin, 2012; Laukenmann et al., 2003; Oludipe \& Awokoy, 2010; McCarthy \& Widanski, 2009; Woldeamanuel et al., 2013), determining laboratory anxiety (Anılan et al., 2009; Bowen, 1999; Eddy, 2000; Kurbanoglu \& Akin, 2010; Malakpa et al., 2013).

Günçer (1982) defines expectation as "Individuals making judgement in consideration of facts and by estimating the performance that they may exhibit in the future" (Erden, 1989). As we examine literature, it is emphasized that morale shall increase as much as the expectations of any individual are satisfied, and that more amount of motivation and job satisfaction shall be obtained (Uras \& Kunt, 2005).

According to the data obtained as a result of several researches, it is observed that laboratory events or test practices are not included at a sufficient level, although there are laboratories in primary and secondary education schools, and that even the tests that may be performed by using materials, which are used in daily life, are not performed (Görgülü et al., 2006; Güneş et al., 2013). In this context, it may be considered that the anxieties and expectations that the students experience throughout the learning process may be the cause of current problem. When we assess the issue from this point of view, by revealing the expectations and anxiety states of students interms of laboratory course, it is aimed in this research to make suggestions that may allow processing of such emotions more effectively and efficiently for meeting the expectations of students and decreasing their anxieties in the laboratory courses that shall be studied in the future. 


\section{Method}

\subsection{Research Model}

In this research, in which the expectation and anxiety states of Science Education students are examined in terms of the course of science education laboratory practices, screening model was used accordingly. Screening models are research approaches that aim to represent any state, which was experienced in the past or which is currently being experienced, as they are. Incidents, individuals or objects that constitute the subject of present research are endeavoured to be identified on their own terms (Karasar, 2009). Within the scope of screening model, it was primarily required from the students to write down their answers to the following question; "What are your expectations from the course of Science education laboratory practices?". Then, Science Laboratory Anxiety Scale was applied to the students. The reason why we asked to the students about their expectations from the course was that, we aimed to ensure that the students are not affected from the statements available in the scale. In this context, sub-problems of the research are emphasized as below:

1) What is the level of the expectations of Science Education students from the course of science education laboratory practices?

2) What is the level of the science laboratory anxieties of Science Education students?

\subsection{Working Group}

This study was carried out with the participation of 83 undergraduates, who took the course of Science Education Laboratory Practice and who were studying in 3rd Grade (3 branches) in the Department of Science Education, Department of Mathematics and Sciences, Faculty of Education, public university in the spring semester of 2016-2017 academic year. 55 (66\%) undergraduates in the sample were female and $28(34 \%)$ were male.

\subsection{Data Collection Tools}

At the qualitative dimension of the research, we asked the following open-ended question and asked students to write down their answers: "What are your expectations from Science laboratory course?". In the quantitative dimension of the study, we used "Science Laboratory Anxiety Scale", which was developed by Uşaklı and Akpınar (2015) as a data collection tool. Scale has 5 sub-dimensions, and these dimensions are named as "sensory", "success", "equipment usage", "assessment" and "chemical material usage". Total variance of the factors is $63,24 \%$. Reliability coefficients range between 76 and 92. General reliability coefficient of the scale is 89 .

\subsection{Data Analysis}

The scale includes 24 items in total, including 18 items that reinforce anxiety (negative) and 6 items that do not reinforce anxiety (positive). Grading was made as below in negative statements made during the assessment of "Science Laboratory Anxiety Scale"; I totally agree = 5, I partially agree = 4, I am indecisive $=3$, I don't agree $=2$ and I don't agree at all $=1$, in the case of positive statements, this grading was made reversely. Accordingly, students, who obtained the highest points from the scale, have a high level of anxiety. SPSS 18.0 statistics package program was used during analysis of data 
obtained from the quantitative dimension of the research. Arithmetic average and standard deviation of the answers, which the students gave to the Science Laboratory Anxiety Scale, were determined by calculating minimum and maximum values according to the sub-dimensions of the scale. Also, frequency and percentage values of the items that were available in the scale were provided. In the qualitative dimension of the research, descriptive analysis technique was used during analysis of the data obtained as a result of the answers that the students gave to the following open-ended question; "What are your expectations from the course of Science laboratory practices?". In descriptive analysis, data were summarized and interpreted according to pre-determined themes (Yıldırım \& Şimşek, 2008). As we made the analyses, various codes were assigned to teacher candidates, such as Ö1, Ö2, Ö3, .. Ö79 and Ö80, etc. Accordingly, data were examined according to five sub-dimensions of Science Laboratory Anxiety Scale, and frequency (f) and percentage (\%) values were provided according to aforementioned themes. Qualitative findings may be determined by using quantitative statements in order to clarify the analysis and to increase its reliability (Yıldırım \& Şimşek, 2008).

\section{Findings}

\subsection{Analysis of the Data Obtained from Science Laboratory Anxiety Scale}

Since the numbers of items available in the sub-dimensions of Science Laboratory Anxiety Scale are different, average points obtained from the sub-dimensions of Science Laboratory Anxiety Scale are transformed into an average that range from 1 to 5 by being divided into the numbers of materials available in relative dimension. Thus, it is ensured that the points obtained by the students from the sub-dimensions may be compared. Below determined ranges were used in the assessment of arithmetic averages obtained from the research: (Tekin, 1993) "1.00-1.80: Very Low", "1.81-2.60: Low", "2.61-3.40: Moderate", "3.41-4.20: High", “4.21-5.00: Very High”. Accordingly, anxiety levels of students are indicated in terms of the laboratory.

Descriptive statistics of the answers that are given to the scale items related with the anxieties of students that source from science laboratory may be seen in Table 1 .

Table 1. Descriptive Statistics on the Laboratory Related Anxieties of Students

\begin{tabular}{llllll}
\hline Dimensions & $\mathrm{N}$ & Lowest Point & Highest Point & $\overline{\mathrm{X}}$ & Ss \\
\hline Sensory & 83 & 1.00 & 4.63 & 2.04 & .64 \\
Success & 83 & 1.00 & 4.50 & 2.44 & .73 \\
Equipment usage & 83 & 1.20 & 4.20 & 2.51 & .65 \\
Assessment & 83 & 1.00 & 4.75 & 2.51 & .79 \\
Chemical material usage & 83 & 1.00 & 4.00 & 2.15 & .82 \\
Total & 83 & 1.08 & 4.29 & 2.30 & .52 \\
\hline
\end{tabular}


As it is determined in Table 1, average point related with the sensory dimension of the Science Laboratory Anxiety Scale of the students is $\overline{\mathrm{X}}=2.04$, standard deviation is $\mathrm{S}=.64$, and average point on "Success" dimension is $\overline{\mathrm{X}}=2.44$, and its standard deviation is $\mathrm{S}=.73$, and average point related with the dimension of "Equipment usage" and "Assessment" is $\overline{\mathrm{X}}=2.51$, and standard deviation is $\mathrm{S}$ $=.65$ and 79 respectively, and average point related with the dimension of "Chemical material usage" is $\overline{\mathbf{X}}=2.15$, and its standard deviation is $\mathrm{S}=.82$. Average point related with total points is $\overline{\mathrm{X}}=2.30$, and its standard deviation is $\mathrm{S}=.522$. Average points of the students related with the sub-dimensions of the scale correspond to low anxiety level in general.

Frequency percentage tables related with these items were established by considering whether the students agree/disagree with the statements that denote anxiety.

Table 2. Sensory Dimension Frequency Percentage Values of Science Laboratory Anxiety Scale

\begin{tabular}{|c|c|c|c|c|c|c|c|c|c|c|}
\hline \multirow[t]{2}{*}{ Item } & \multicolumn{2}{|c|}{$\begin{array}{l}\text { I totally } \\
\text { agree }\end{array}$} & \multicolumn{2}{|c|}{$\begin{array}{l}\text { I partially } \\
\text { agree }\end{array}$} & \multicolumn{2}{|c|}{$\begin{array}{l}\text { I am } \\
\text { indecisive }\end{array}$} & \multicolumn{2}{|c|}{$\begin{array}{l}\text { I don't } \\
\text { agree }\end{array}$} & \multicolumn{2}{|c|}{$\begin{array}{l}\text { I don't } \\
\text { agree at all }\end{array}$} \\
\hline & f & $\%$ & $\mathrm{f}$ & $\%$ & $\mathrm{f}$ & $\%$ & $\mathrm{f}$ & $\%$ & $\mathrm{f}$ & $\%$ \\
\hline $\begin{array}{l}\text { I act angrily towards my friends } \\
\text { during a test. }\end{array}$ & 3 & 3,6 & 5 & 6,0 & 4 & 4,8 & 31 & 37,3 & 40 & 48,2 \\
\hline $\begin{array}{l}\text { I feel myself uncomfortable in } \\
\text { the laboratory. }\end{array}$ & 1 & 1,2 & 4 & 4,8 & 7 & 8,4 & 33 & 39,8 & 38 & 45,8 \\
\hline $\begin{array}{l}\text { I feel very happy when I am } \\
\text { doing a test. }\end{array}$ & 2 & 2,4 & 3 & 3,6 & 9 & 10,8 & 37 & 44,6 & 32 & 38,6 \\
\hline $\begin{array}{l}\text { I always feel uncomfortable } \\
\text { before entering to the laboratory. }\end{array}$ & 3 & 3,6 & 7 & 8,4 & 9 & 10,8 & 33 & 39,8 & 31 & 37,3 \\
\hline $\begin{array}{l}\text { I always think that something } \\
\text { negative will happen to me in the } \\
\text { laboratory. }\end{array}$ & 3 & 3,6 & 1 & 1,2 & 7 & 8,4 & 37 & 44,6 & 35 & 42,2 \\
\hline $\begin{array}{l}\text { I feel comfortable in the } \\
\text { laboratory. }\end{array}$ & 2 & 2,4 & 7 & 8,4 & 8 & 9,6 & 31 & 37,3 & 35 & 42,2 \\
\hline $\begin{array}{l}\text { I feel uneasy about others } \\
\text { disturbing me during a test. }\end{array}$ & 11 & 13,3 & 32 & 38,6 & 9 & 10,8 & 21 & 25,3 & 10 & 12,0 \\
\hline $\begin{array}{l}\text { I feel that my heart beats rapidly } \\
\text { during a test. }\end{array}$ & 1 & 1,2 & 4 & 4,8 & 19 & 22,9 & 32 & 38,6 & 27 & 32,5 \\
\hline
\end{tabular}

As we examine Table 2, ratio of the students, who feel anxious in relation with the item where it is stated that "I act angrily towards my friends during a test", is $9,6 \%$. This ratio is $6 \%$ in relation with the item where it is stated that "I feel uncomfortable in the laboratory". The ratio of the students, who 
answered the item related with the statement of "I feel very happy during a test", is $83,2 \%$. The ratio of the students, who feel anxious in relation with the item where it is stated that "I always feel uncomfortable before entering to the laboratory", is $12 \%$. The ratio of the students, who feel anxious in relation with the item where it is stated that "I always think that something negative will happen to me in the laboratory", is $4,8 \%$. The ratio of the students, who answered negatively the item where it is stated that "I feel comfortable in the laboratory", is $79,5 \%$. The ratio of the students, who feel anxious in relation with the item where it is stated that "I feel uneasy about others disturbing me during a test", is $52 \%$. The ratio of the students, who feel anxious in relation with the item where it is stated that "I feel that my heart beats rapidly during a test", is $6 \%$. In sensory dimension, students feel anxious the most in relation with the item where it is stated that "I feel very happy during a test" $(83,2 \%)$.

Table 3. Success Dimension Frequency Percentage Values of Science Laboratory Anxiety Scale

\begin{tabular}{|c|c|c|c|c|c|c|c|c|c|c|}
\hline \multirow[t]{2}{*}{ Item } & \multicolumn{2}{|c|}{$\begin{array}{l}\text { I totally } \\
\text { agree }\end{array}$} & \multicolumn{2}{|c|}{$\begin{array}{l}\text { I partially } \\
\text { agree }\end{array}$} & \multicolumn{2}{|c|}{$\begin{array}{l}\mathrm{I} \quad \mathrm{am} \\
\text { indecisive }\end{array}$} & \multicolumn{2}{|c|}{$\begin{array}{l}\text { I don't } \\
\text { agree }\end{array}$} & \multicolumn{2}{|c|}{$\begin{array}{l}\text { I don't } \\
\text { agree at all }\end{array}$} \\
\hline & $\mathrm{f}$ & $\%$ & $\mathrm{f}$ & $\%$ & $\mathrm{f}$ & $\%$ & $\mathrm{f}$ & $\%$ & $\mathrm{f}$ & $\%$ \\
\hline $\begin{array}{l}\text { I never think whether a test will } \\
\text { be completed successfully or not. }\end{array}$ & 4 & 4,8 & 10 & 12,0 & 11 & 13,3 & 40 & 48,2 & 18 & 21,7 \\
\hline $\begin{array}{l}\text { I fear that I will interpret } \\
\text { inaccurately the data I obtained } \\
\text { from a test. }\end{array}$ & 10 & 12,0 & 27 & 32,5 & 18 & 21,7 & 22 & 26,5 & 6 & 7,2 \\
\hline $\begin{array}{l}\text { I can't help myself to think of the } \\
\text { results of being unsuccessful } \\
\text { during a test. }\end{array}$ & 3 & 3,6 & 7 & 8,4 & 9 & 10,8 & 38 & 45,8 & 26 & 31,3 \\
\hline $\begin{array}{l}\text { I always have the fear whether I } \\
\text { will obtain an accurate result by } \\
\text { making a test. }\end{array}$ & 2 & 2,4 & 12 & 14,5 & 12 & 14,5 & 36 & 43,4 & 21 & 25,3 \\
\hline
\end{tabular}

As we examine Table 3, ratio of the students, who answered negatively the item where it is stated that "I never think whether a test will be completed successfully or not", is $70 \%$. The ratio of the students, who feel anxious in relation with the item where it is stated that "I fear that I will interpret inaccurately the data I obtained from a test", is $44,5 \%$. The ratio of the students, who answered positively the item where it is stated that "I can't help myself to think of the results of being unsuccessful during a test", is $12 \%$. The ratio of the students, who feel anxious in relation with the item where it is stated that "I always have the fear whether I will obtain an accurate result by making a test", is $17 \%$. In success dimension, students feel anxious the most in relation with the item where it is stated that "I never think whether a test will be completed successfully or not" $(70 \%)$. 
Table 4. Equipment Usage Dimension Frequency Percentage Values of Science Laboratory Anxiety Scale

\begin{tabular}{|c|c|c|c|c|c|c|c|c|c|c|}
\hline \multirow[t]{2}{*}{ Item } & \multicolumn{2}{|c|}{$\begin{array}{l}\text { I totally } \\
\text { agree }\end{array}$} & \multicolumn{2}{|c|}{$\begin{array}{l}\text { I partially } \\
\text { agree }\end{array}$} & \multicolumn{2}{|c|}{$\begin{array}{l}\mathrm{I} \quad \mathrm{am} \\
\text { indecisive }\end{array}$} & \multicolumn{2}{|c|}{ I don't agree } & \multicolumn{2}{|c|}{$\begin{array}{l}\text { I don't agree } \\
\text { at all }\end{array}$} \\
\hline & $\mathrm{f}$ & $\%$ & $\mathrm{f}$ & $\%$ & $\mathrm{f}$ & $\%$ & $\mathrm{f}$ & $\%$ & $\mathrm{f}$ & $\%$ \\
\hline $\begin{array}{l}\text { It prevents me from paying } \\
\text { attention to the test to think } \\
\text { that the equipment will break } \\
\text { during a test. }\end{array}$ & 1 & 1,2 & 6 & 7,2 & 15 & 18,1 & 31 & 37,3 & 30 & 36,1 \\
\hline $\begin{array}{l}\text { I think that electric equipment } \\
\text { will break down as I use them. }\end{array}$ & 1 & 1,2 & 8 & 9,6 & 14 & 16,9 & 35 & 42,2 & 25 & 30,1 \\
\hline $\begin{array}{l}\text { I always have the fear that I } \\
\text { will not find the suitable } \\
\text { equipment for a test. }\end{array}$ & 2 & 2,4 & 8 & 9,6 & 15 & 18,1 & 36 & 43,4 & 22 & 26,5 \\
\hline $\begin{array}{l}\text { I never think whether the } \\
\text { materials will break down } \\
\text { while making a test. }\end{array}$ & 9 & 10,8 & 29 & 34,9 & 27 & 32,5 & 13 & 15,7 & 5 & 6,0 \\
\hline $\begin{array}{l}\text { I am not scared of making tests } \\
\text { with various living creatures, } \\
\text { such as snakes and rats, etc. }\end{array}$ & 19 & 22,9 & 14 & 16,9 & 14 & 16,9 & 20 & 24,1 & 16 & 19,3 \\
\hline
\end{tabular}

As we examine Table 4, ratio of the students, who feel anxious in relation with the item where it is stated that "It prevents me from paying attention to the test to think that the equipment will break during a test", is $8,4 \%$. The ratio of the students, who feel anxious in relation with the item where it is stated that "I think that electric equipment will break down as I use them", is $10,8 \%$. The ratio of the students, who feel anxious in relation with the item where it is stated that "I always have the fear that I will not find the suitable equipment for a test", is $12 \%$. The ratio of the students, who answered negatively the item where it is stated that "I never think whether the materials will break down while making a test", is $21,7 \%$. The ratio of the students, who answered negatively the item where it is stated that "I am not scared of making tests with various living creatures, such as snakes and rats, etc.", is $43,4 \%$. In equipment usage dimension, students feel anxious the most in relation with the item where it is stated that "I am not scared of making tests with various living creatures, such as snakes and rats, etc." $(43,4 \%)$. 
Table 5. Assessment Dimension Frequency Percentage Values of Science Laboratory Anxiety Scale

\begin{tabular}{|c|c|c|c|c|c|c|c|c|c|c|}
\hline \multirow[t]{2}{*}{ Item } & \multicolumn{2}{|c|}{$\begin{array}{l}\text { I totally } \\
\text { agree }\end{array}$} & \multicolumn{2}{|c|}{$\begin{array}{l}\text { I partially } \\
\text { agree }\end{array}$} & \multicolumn{2}{|c|}{$\begin{array}{l}\mathrm{I} \quad \mathrm{am} \\
\text { indecisive }\end{array}$} & \multicolumn{2}{|c|}{ I don't agree } & \multicolumn{2}{|c|}{$\begin{array}{l}\text { I don't agree } \\
\text { at all }\end{array}$} \\
\hline & $\mathrm{f}$ & $\%$ & $\mathrm{f}$ & $\%$ & $\mathrm{f}$ & $\%$ & $\mathrm{f}$ & $\%$ & $\mathrm{f}$ & $\%$ \\
\hline $\begin{array}{l}\text { I feel anxious about the fact } \\
\text { that a question will be asked to } \\
\text { me during a test. }\end{array}$ & 2 & 2,4 & 17 & 20,5 & 22 & 26,5 & 28 & 33,7 & 14 & 16,9 \\
\hline $\begin{array}{l}\text { It causes me to forget all I } \\
\text { know when I am asked a } \\
\text { question during a test. }\end{array}$ & 2 & 2,4 & 11 & 13,3 & 14 & 16,9 & 34 & 41,0 & 22 & 26,5 \\
\hline $\begin{array}{l}\text { I don't feel anxious at all that } \\
\text { the laboratory exam is a } \\
\text { practical exam. }\end{array}$ & 13 & 15,7 & 15 & 18,1 & 16 & 19,3 & 25 & 30,1 & 14 & 16,9 \\
\hline $\begin{array}{l}\text { I hate from the assessment of } \\
\text { test results continuously. }\end{array}$ & 2 & 2,4 & 10 & 12,0 & 20 & 24,1 & 38 & 45,8 & 13 & 15,7 \\
\hline
\end{tabular}

As we examine Table 5, ratio of the students, who feel anxious in relation with the item where it is stated that "I feel anxious about the fact that a question will be asked to me during a test", is $23 \%$. The ratio of the students, who feel anxious in relation with the item where it is stated that "It causes me to forget all I know when I am asked a question during a test", is $15,7 \%$. The ratio of the students, who feel anxious in relation with the item where it is stated that "I don't feel anxious at all that the laboratory exam is a practical exam", is $47 \%$. The ratio of the students, who feel anxious in relation with the item where it is stated that "I hate from the assessment of test results continuously", is $14,4 \%$. In assessment dimension, students feel anxious the most in relation with the item where it is stated that "I don't feel anxious at all that the laboratory exam is a practical exam" (47\%).

Table 6. Chemical Material Usage Dimension Frequency Percentage Values of Science Laboratory Anxiety Scale

\begin{tabular}{|c|c|c|c|c|c|c|c|c|c|c|}
\hline \multirow[t]{2}{*}{ Item } & \multirow{2}{*}{$\begin{array}{l}\mathrm{I} \\
\mathrm{a} \\
\mathrm{f}\end{array}$} & $\begin{array}{l}\text { totally } \\
\text { ee }\end{array}$ & \multicolumn{2}{|c|}{$\begin{array}{l}\text { I partially } \\
\text { agree }\end{array}$} & \multicolumn{2}{|c|}{$\begin{array}{l}\text { I am } \\
\text { indecisive }\end{array}$} & \multicolumn{2}{|c|}{ I don't agree } & \multicolumn{2}{|c|}{$\begin{array}{l}\text { I don't agree } \\
\text { at all }\end{array}$} \\
\hline & & $\%$ & $\mathrm{f}$ & $\%$ & $\mathrm{f}$ & $\%$ & $\mathrm{f}$ & $\%$ & $\mathrm{f}$ & $\%$ \\
\hline $\begin{array}{l}\text { It always makes me anxious to } \\
\text { make tests in relation with acids. }\end{array}$ & - & - & 11 & 13,3 & 13 & 15,7 & 34 & 41,0 & 25 & 30,1 \\
\hline $\begin{array}{l}\text { I am scared mixing acids and } \\
\text { bases with each other. }\end{array}$ & - & - & 10 & 12,0 & 10 & 12,0 & 36 & 43,4 & 27 & 32,5 \\
\hline
\end{tabular}




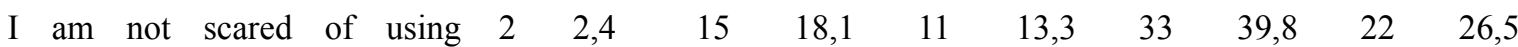

chemical materials.

As we examine Table 6, ratio of the students, who feel anxious in relation with the item where it is stated that "It always makes me anxious to make tests in relation with acids", is $13,3 \%$. While the ratio of the students, who feel anxious in relation with the item where it is stated that "I am scared mixing acids and bases with each other", is $12 \%$, the ratio of the students, who feel anxious in relation with the item where it is stated that "I am not scared of using chemical materials", is $66,3 \%$. In chemical material usage dimension, students feel anxious the most in relation with the item where it is stated that "I am not scared of using chemical materials" (66,3\%).

\subsection{Findings Obtained from the Analysis of Qualitative Data}

In this research, expectations of the students from the course of science education laboratory practices is themed in consideration of the dimensions available in the Science laboratory anxiety scale, and frequency (f) and percentage (\%) values are given in Table 7.

Table 7. Expectations of the Students from Science Laboratory Course

\begin{tabular}{lll}
\hline Themes & $\mathrm{f}$ & $\%$ \\
\hline Sensory & 10 & 11.11 \\
Success & 41 & 45.55 \\
Assessment & 23 & 25.55 \\
Equipment usage & 11 & 12.22 \\
Chemical material usage & 5 & 5.55 \\
Total & 90 & 100 \\
\hline
\end{tabular}

In Table 7, it is observed that the expectation states of 83 students from the course of science education laboratory practices are focused on the success dimension ( $f=41$ ) the most, and then, on the dimensions of assessment $(f=23)$, equipment usage $(f=11)$, sensory $(f=10)$ and chemical material usage $(f=5)$ respectively.

The statements that the students made in the direction of their expectations in relation with sensory dimension may be exemplified as below: "I would like to complete the course with love and respect, and without hurting each other (Ö3)", "I wish my teachers are always good-humoured and tolerable (Ö7)", "Doing a course enjoyably without being boring and showing mutual understanding (Ö8)", and "A course that is done by thinking how should I teach in the 3rd Grade so that I may raise interest and curiosity (Ö2)". Students stated their expectations in relation with assessment dimension as below: "Passing from the course and not to be subjected to quizzes every week (Ö11)", "I would like make progress in laboratory course without the fear of grade (Ö17)", and "To make the course more 
understandable by applying the information, which we learned theoretically (Ö9)". Certain statements that the students made in relation with equipment usage dimension are as below: "Laboratory materials must be used carefully. Each student must prepare his/her preparation and may examine samples under the microscope (Ö9)", "I don’t want students to be held responsible for material supply (Ö10)", "To learn using laboratory materials in a better way (Ö11)", "Material usage must not be limited (Ö23)", and "To learn the names of materials completely, as well as how to use them neatly, and to become a conscious science teacher in my professional career with the completion of 4 years (Ö65)". The statements that the students made in the direction of their expectations in relation with success dimension may be exemplified as below: "An environment, in which every student is active, must be provided during a course (Ö5)", "To ensure that our students understand tests more easily in the future by making sufficient number of tests in the laboratory course (Ö12)", "To ensure that learning by doing-experiencing takes place (Ö18)", and "I would like to make tests like a scientist (Ö15)". Students stated their expectations in relation with chemical material usage dimension as below: "To ensure that the tests are performed with different materials in case there is any material lacking (Ö70)", "We managed to dilute concentrated acids without you (Ö24)", and "To be an individual, who adopts laboratory safety measures (Ö56)".

\section{Discussion and Conclusion}

In this research, we examined the expectations and anxiety states of students, who are studying Science Education, in terms of the course of science education laboratory practices. According to the findings obtained from the research, average anxiety rate of the students is 31,63 in sensory dimension, average anxiety rate is $35,87 \%$ in success dimension, average anxiety rate is $19,26 \%$ in equipment usage dimension, average anxiety rate is $25,02 \%$ in assessment dimension, and average anxiety rate is $30,53 \%$ in chemical material usage. Accordingly, it may be stated that the students have anxiety in terms of science laboratory in all of the five dimensions.

It is observed that the expectation states of students from the course of science education laboratory practices are focused on the success dimension $(f=41)$ the most, and then, on the dimensions of assessment ( $f=23$ ), equipment usage $(f=11)$, sensory $(f=10)$ and chemical material usage $(f=5)$ respectively.

It is observed that the expectations and anxieties of students focus on success dimension the most. Students are anxious whether any test will be concluded successfully and whether they will interpret inaccurately the data that they obtained. This situation makes it difficult for the students to understand any test, and thus, prevents the students from understanding the subject. However, students expect to be active in terms of success dimension, and to learn by doing and experiencing relative activities and to relate the subject with daily life by understanding it. Students wish to make the course more understandable by practicing the information that they learned theoretically. This situation will increase the applicability of any of the information and skills, which they learned in the laboratory, in daily life. 
Otherwise, a course of science laboratory, in which abstract rules based on memorization, may be considered as nothing but a course that causes anxiety among students.

It is one of the reasons, why students feel anxious in the education process, that the teacher's failure to perform what he/she expects from himself/herself and desire to become successful vs. fear of being unsuccessful (Erden \& Akman, 1997, p. 112). A student, who thinks that the academic member, who gives the course, will get angry at him/her since he can not find the result of any test, may not focus on the test. Students must not refrain from making comments on the test. They must know that their unique comments are valuable, even if they are inaccurate. It may be ensured that such anxieties are decreased to allow the students know that the result of any test will not effect the grade he/she will obtain from relative course.

It is observed that the anxieties of students in terms of sensory dimension are as below; feeling uncomfortable in laboratory course and feeling anxious in their relations with their friends. Following are among the expectations of the students; teacher's being good-humoured and tolerable, and doing courses with respect and love. It may cause performance anxiety for the students to make a test by preparing test setup in front of the laboratory assistant and other students (Uşaklı \& Akpınar, 2015). Physiological, behavioural and cognitive characteristics of performance anxiety (Miller, 2006) are determined in the literature. In this context, academic member, who gives the course, must establish a learning environment, in which students may understand and perform tests individually and as a group, in which students may think comfortably and in which the interaction between teacher and students is strong.

Regarding assessment dimension, students are anxious for the exam of laboratory course being practical. Likewise, students expect to pass from any course without any fear of grade and not to be subjected to a quiz every week. One may observe a different type of anxiety that sources from valid examination strategies for all of the exams in general as a test is being made in the laboratory course (Uşaklı \& Akpınar, 2015). Yücel (2014) defines the anxiety of being assessed in the laboratory environment as a disliked emotion or an emotive state, which is comprised of cognitive, affective and behavioural components that are experienced in any assessment environment. If any student gives a wrong answer during an examination, academic member must guide him/her to find the correct answer with a constructive approach, and must refrain from abusing their self-esteems. Thus, students will be encouraged and will make their comments on the test completely and timely.

Regarding chemical material usage dimension, students emphasized that they are scared of using chemical materials. Their expectation is to become an individual, who adopts laboratory safety measures. It may be the cause of this situation that the students do not participate to any effective laboratory course until they come to university, and that they do not know materials completely. Most of the teachers do not organize any laboratory practices or use the method of limited number of demonstration test method since the chemical materials and test equipment in the laboratory are insufficient (Ayas, Çepni, \& Akdeniz, 1993; Nakiboğlu \& Sarıkaya, 1999). Location of fire 
extinguishers and first aid materials must be shown to the students in the first course. Names of chemical materials must be adhered on relative cabinets together with relative specifications. The method of using chemical materials must be demonstrated to the students in practice.

As we examined the anxiety states of students in terms of equipment usage in the laboratory, they stated that they are scared of making tests on various living creatures, such as snakes and rats etc. It may be observed that the tests related with various inflammable and combustible materials, such as alcohol and hydrochloric acid, etc., or various animals, such as snakes and frogs, etc., may cause the students to feel negative emotions, such as anxiety, fear and reluctance, etc. (Uşaklı \& Akpınar, 2015). Students wish to prepare their own preparations, to examine the same under a microscope and to have sufficient number of materials in the laboratory. However, supplying sufficient number of laboratory materials does not make a laboratory functional by itself. Also, ability of teacher candidates, who shall perform laboratory practises in the future, to use laboratory materials properly and timely is also important from the perspective of an effective science education (Coştu, Ayas, Çalık, Ünal, \& Karataş, 2005).

Regarding elimination of the anxieties that the students experience at various dimensions in the science laboratory in consideration of research results, relative academic member, who gives relative course, must be aware of the anxieties that used to exist or that may occur afterwards, and must take measures against the reasons of such anxieties.

\section{Implications}

For students having constant anxiety towards the science laboratory, motivating environments, which would make the lesson more enjoyable, can be created and applications can be performed. Teachers can prefer more enjoyable and more interesting experimentsin laboratory applications. Teachers also need to be aware of the effects of anxiety on students' achievement and motivation during their training. So, they should show their students a sincere, caring attitude to help them overcome science anxiety. Teachers should use cooperative grouping to help students understand that others have the same problems as they do. They should create an environment in which students do not feel threatened and allow them to relax. Materials can be introduced and their usage can be explained before the experiment.

\section{References}

Anılan, B., Görgülü, A., \& Balbağ, M. Z. (2009). Öğretmen adaylarının kimya labora tuarı end işeleri. e-Journal of New World Sciences Academy Education Sciences, 4(2), 575-594.

Ayas, A., Çepni, S., \& Akdeniz, A. R. (1993). Development of the Turkish secondary sciencecurriculum. Science Education, 77(4), 433-440. https://doi.org/10.1002/sce.3730770406

Bloom, B. S. (1979). Insan nitelikleri ve okulda öğrenme. Milli Eğitim Basımevi, Ankara.

Bowen, C. W. (1999). Development and score validation of a Chemistry Laboratory Anxiety 
Instrument (CLAI) for college chemistry students. Educational and Psychological Measurement, 59(1), 171-187. https://doi.org/10.1177/0013164499591012

Çallıca, H., Erol, M., Sezgin, G., \& Kavcar, N. (2001). Illköğretim kurumlarında laboratuvar kullanımına iliş̧kin bir çalışma. IV. Fen Bilimleri Kongresi, Ankara: MEB. Basımevi.

Coştu, B., Ayas, A., Çalık, M., Ünal, S., \& Karataş, F. Ö. (2005). Fen öğretmen adaylarının çözelti hazırlama ve laboratuvar malzemelerini kullanma yeterliliklerinin belirlenmesi. Hacettepe Üniversitesi Ĕgitim Fakültesi Dergisi, 28, 65-72

Czemiak, C., \& Chiarelott, L. (1984). Science anxiety: An investigation of science achievement, sex and grade level factors. Paper presented at the 68th Annual Meeting of the American Educational Research Association, New Orleans, LA.

Eddy, R. M. (2000). Chemo-phobia in the college classroom: Extent, sources, and student characteristics. Journal of Chemical Education, 77, 514. https://doi.org/10.1021/ed077p514

Erden, M. (1989). Hacettepe Üniversitesi Eğitim Bilimleri Bölümü öğrencilerinin meslekleri ile ilgili beklentileri. Hacettepe Üniversitesi Eğitim Fakültesi Dergisi, 4, 93-107.

Erden, M., \& Akman, Y. (1997). Eğitim Psikolojisi. Ankara: Arkadaş Yayınevi.

Freud, S. (1969). The Problem of Anxiety. New York: Norton.

Görgülü, A., Balbağ, M. Z., Anılan, H., Anılan, B., \& Çemrek, F. (2006). Öğretmen adaylarının ortaöğretim okullarındaki laboratuvar kullanımına ilişkin görüşleri (Vol. 15). Ulusal Eğitim Bilimleri Kongresi.

Güneş, M. H., Şener, N., Germi, N. T., \& Can, N. (2013). Fen ve teknoloji dersinde laboratuvar kullanımına yönelik öğretmen ve öğrenci değerlendirmeleri. Dicle Üniversitesi Ziya Gökalp Eğitim Fakültesi Dergisi, 20, 1-11.

Hofstein, A., \& Lunetta, V. N. (2004). The laboratory in science education: Foundations for the twentyfirst century. Science Education, 88(1), 28-54. https://doi.org/10.1002/sce.10106

Huey, C. C. S. (2013). Assessment of chemistry anxiety among college students. Chemistry Education and Sustainability in the Global Age, 27-34. https://doi.org/10.1007/978-94-007-4860-6_3

Karasar, N. (2009). Bilimsel Araştırma Yöntemi (20. Baskı). Ankara: Nobel Yayın Dağııım.

Kurbanoglu, N. I., \& Akin, A. (2010). The relationships between university students' chemistry laboratory anxiety, attitudes, and self-efficacy beliefs. Australian Journal of Teacher Education, 35(8), 48-59. https://doi.org/10.14221/ajte.2010v35n8.4

Kurbanoglu, N. I., \& Akin, A. (2012). The relationships between university students' organic chemistry anxiety, chemistry attitudes, and self efficacy: A structural equation model. Journal of Baltic Science Education, 11(4).

Laukenmann, M., Bileicher, M., Fu, S., Glaser-Zikuda, M., Mayring, P., \& Von Rhöneck, C. (2003). An investigation of the influence of emotional factors on learing in physics instruction. International Journal of Science Education, 25(4), 489-507. https://doi.org/10.1080/09500690210163233

Malakpa, Z., Jensen, J., \& Bretz, S. L. (2013). Investigating student anxiety within the chemistry 
laboratory. Abstracts of Papers of the American Chemical Society, 245, 1155.

Mallow, J. V. (1986). Science anxiety: Fear of science and how to overcome it. Clearwater, FL: H \& H Publishing Co.

Mccarthy, W. C., \& Widanski, B. B. (2009). Assessment of chemistry anxiety in a two-year college. Journal of Chemical Education, 86(12), 1447-1449. https://doi.org/10.1021/ed086p1447

Miller, C. B. (2006). A discussion on performance anxiety. Retrievd from http://www.mostlywind.co.uk

Nakiboglu, C., \& Sarıkaya, S. (1999). Ortaöğretim kurumlarında kimya derslerinde görevli öğretmenlerin laboratuvardan yararlanma durumunun değerlendirilmesi. Dokuz Eylül Üniversitesi Buca Eğitim Fakültesi Dergisi, 11, 395-405.

Odubunni, O., \& Balagun, T. A. (1991). The Effect of Laboratory and Lecture Teaching Methods on Cognitive Achivement İn İntegrated Science. Journal of Researrch in Science Teaching, 28, 213-224. https://doi.org/10.1002/tea.3660280303

Oludipe, D., \& Awokoy, J. O. (2010). Effect of cooperative learning teaching strategy on the reduction of students' anxiety for learning chemistry. Journal of Turkish Science Education, 7(1).

Shulman, L. S., \& Tamir, P. (1973). Research on Teaching in the Natural Sciences. In R. M. W. Travers (Ed.), Second Handbook of Research on Teaching, 1098-1148. Chicago: Rand McNally \& Co.

Tekin, H. (1993). Eğitimde Ölçme ve Değerlendirme. yargı yayınları (7.Baskı), Ankara.

Uras, M., \& Kunt, M. (2005). Öğretmen Adaylarının Öğretmenlik Mesleğinden Beklentileri ve Beklentilerinin Karşılanmasını Umma Düzeyleri [Bildiri]. XIV. In Eğitim Bilimleri Kongresi (pp. 23-30). Eylül 2005, Denizli.

Uşaklı, H., \& Akpınar, E. (2015). Fen Laboratuvarı Kaygı Ölçeğinin (FLKÖ) Geliştirilmesi. K.Ü. Kastamonu Ĕ̈itim Dergisi, 23(3), 1241-1250.

Woldeamanuel, M., Atagana, H., \& Engida, T. (2013). Students' anxiety towards the learning of chemistry in some ethiopian universities. African Journal of Chemical Education, 3(2), 28-38.

Yıldırım, A., \& Şimşek, H. (2008). Sosyal bilimlerde nitel araştırma yöntemleri (6. Baskı). Ankara: Seçkin Yayınları.

Yücel, E. (2014). Fen Bilgisi Öğretmen Adaylarının Laboratuvar Derslerine Yönelik Öz-Yeterlik, Tutum Ve Kaygı Puanlarının Bazı Değişsenlere Göre İncelenmesi (Yayımlanmamış Yüksek Lisans Tezi). Sakarya Üniversitesi, Eğitim Bilimleri Enstitüsü, Sakarya. 